\title{
Ratification of the 1995 UNIDROIT Convention on Stolen or Illegally Exported Cultural Objects, in Light of Directive 2014/60/UE on the Return of Cultural Objects Unlawfully Removed from the Territory of a Member State: The Perspective of Poland
}

\begin{abstract}
This article explores the relationship between the regime of the 1995 UNIDROIT Convention on Stolen or Illegally Exported Cultural Objects and the Directive 2014/60/EU from the perspective of the Polish legislative experience. In fact, Poland is just about to ratify the 1995 UNIDROIT Convention. Consequently, a two-level system for the protection of movable cultural heritage will be established: the 1995 UNIDROIT and the EU Directive 2014/60. This article critically discusses how such a complex system is going to be introduced to the existing legal framework in the area of cultural heritage. It also endeavours to foresee how both instruments will practically operate together.
\end{abstract}

\footnotetext{
* Wojciech W. Kowalski is Full Professor in Civil Law at the University of Silesia, Katowice and head of the Department of Intellectual and Cultural Property Laws of this University. In 2001, he gave a Summer Course in the Hague Academy of International Law on the restitution of works of art pursuant to private and public international law. At the Ministry of Foreign Affairs of Poland, he is responsible for the implementation of Poland's government foreign policy aimed at liquidating the effects of WWII in the area of culture and cultural heritage. His monograph Art Treasures and War: A Study on the Restitution of Looted Cultural Property Pursuant to Public International Law has been recently reissued by the Institute of Art and Law (United Kingdom).
} 


\section{RESEARCH ARTICLES}

Wojciech W. Kowalski

Keywords: UNIDROIT, Directive 2014/60/EU, illicit export, restitution, Poland

Poland is about to join the 1995 UNIDROIT Convention on Stolen or Illegally Exported Cultural Objects (hereinafter: 1955 UNIDROIT Convention). ${ }^{1}$ While the need to ratify this important act seems obvious, it also raises some doubts with respect to its future execution. The situation is unclear in the context of Poland's obligations resulting from Directive 2014/60/EU on the return of cultural objects unlawfully removed from the territory of a Member State (hereinafter: Directive 2014/60/EU). ${ }^{2}$ Generally, while a bird's eye view of the international export control system created, inter alia, by these two documents seems relatively clear, a careful analysis of its details reveals several practical and theoretical problems in its day to day application. It provides for the full control of exports of cultural objects within the European Union (EU), including the possibility of requesting the return of objects unlawfully removed from a Member State. There is also control of exports outside the $\mathrm{EU},{ }^{3}$ but generally this does not provide for the recovery of object/s removed without the authorisation of a country outside the EU, unless the recovery arises from special agreements or the internal rules of the country concerned. While this is possible upon accession to the 1995 UNIDROIT Convention, it obviously only applies to countries that are parties to this treaty.

As mentioned, the international export control system in theory appears to be a clear structure, but Poland may encounter some problems applying it in practice. As is often said, "the devil is in the detail" and this article discusses several critical details. It begins with commentary on the application of EU law, to lay out the background for the later discussion of the effects of ratification of the 1995 UNIDROIT Convention. Following that, the context of the 1970 UNESCO Convention on the Means of Prohibiting and Preventing the Illicit Export, Import and Transfer of Ownership of Cultural Property (hereinafter: 1970 UNESCO Convention) ${ }^{4}$ is presented. Finally, the article offers some conclusions from the analysis of all the acts devoted to the protection of the integrity of national cultural heritage.

\footnotetext{
124 June 1995, 34 ILM 1322; UNIDROIT Convention on Stolen or Illegally Exported Cultural Objects: Explanatory Report, "Uniform Law Review" 2001, Vol. 3, p. 477 ff.; see also L.V. Prott, Commentary on the UNIDROIT Convention, Institute of Art and Law, Leicester 1997.

2 Directive 2014/60/EU of the European Parliament and the Council of 15 May 2014 on the return of cultural objects unlawfully removed from the territory of a Member State and amending Regulation (EU) No. 1024/2012 (Recast), OJ L 159, 28.05.2014, p. 1. See also A.M. Compagna, P. Petraroia (eds.), Beni culturali e Mercato Europeo. Norme sull'esportazione nei paesi della Comunità, IPZS, Roma 1991.

3 Council Regulation (EEC) No. 3911/92 of 9 December 1992 on the export of cultural goods, OJ L 395 , 31.12.1992, p. 1 , as amended.
}

414 November 1970, 823 UNTS 231. 
Problems are bound to appear with the application of Directive 2014/60/EU, which has widened the range of objects exported without a licence that are recoverable under EU law. This is because it no longer contains the extensive limitations on the range of cultural objects to be recovered, which were previously specified in the 14 categories (sub-categorised by age and/or financial value) in the earlier 1993 Directive. ${ }^{5}$ It was previously specified, for example, that it was possible to request the return of only those paintings whose value exceeded EUR 150,000; old prints that were at least one hundred years old prior to their removal, provided their value was in excess of EUR 50,000; maps that were more than 200 years old and worth more than EUR 15,000, etc. ${ }^{6}$

Under the current, binding Directive 2014/60/EU, the determination of cultural goods to be returned is left entirely to the individual states. It has only been indicated that this Directive applies to the return of cultural objects classified or defined by a Member State, before or after their unlawful removal from the territory of that Member State, as being among the "national treasures possessing artistic, historic or archaeological value" under national legislation or administrative procedures within the meaning of Article 36 TFEU (Articles 1 and 2 of the Directive). It follows from this that goods to be returned will be defined in two ways: (1) either as those goods which are covered by the general term of "cultural goods" included in the legal definition set out in a relevant act enacted by a given state to protect its cultural heritage; or (2) as those listed in an official register of monuments. The first instances of States' reactions to the Directive show that its range of application can be very broad, going far beyond the definition set out in the version of the Directive applicable until 2014 (Council Directive 93/7/EEC). France, ${ }^{7}$ which in February 2015 was the first country to implement Directive 2014/60/EU into its legal system, ${ }^{8}$ applied the relevant definition provided in the Code du patrimoine ${ }^{9}$ to designate its national treasures. This definition is a very broad one, as

5 Council Directive 93/7/EEC of 15 March 1993 on the return of cultural objects unlawfully removed from the territory of a Member State, OJ L 74, 27.03.1993, p. 74. For commentary, see, for example, J. De Ceuster, Les règles communautaires en matière de restitution de biens culturels ayant quitté illicitement le territoire d'un Etat membre Analyse de la directive 93/7/CEE du 15 mars 1993, "Revue du Marché Unique Européen" 1993, Vol. 2, p. 34 ff.

6 Council Directive 93/7/EEC, Annex. Categories referred to in the second indent of Article 1 (1), to which objects classified as "national treasures" within the meaning of Article 36 of the Treaty on the Functioning of the European Union (hereinafter: TFEU (consolidated version), OJ C 202, 7.06.2016, p. 47) must belong in order to qualify for return under this Directive: A. 3, A 9 and A. 10.

7 See further: P. Stec, Dyrektywa 93/7/EWG z perspektywy dwóch dekad funkcjonowania [Directive 93/7/ EEC: a twenty-year retrospective], "Santander Art and Culture Law Review" 2015, Vol. 1(1), p. $103 \mathrm{ff}$.

8 Loi no 2015-195 du 20 février 2015 portant diverses dispositions d'adaptation au droit de l'Union européenne dans les domaines de la propriété littéraire et artistique et du patrimoine culturel [Law No. 2015-195 of 20 February 2015 adapting various provisions of the law of the European Union law in the fields of literary and artistic property and cultural heritage], NOR: MCCB1421649L. See also the article by S. Vigneron in this volume.

9 Code du patrimoine (consolidated version), https://www.legifrance.gouv.fr/affichCode.do?cidTexte=LEGITEXT000006074236 [accessed: 12.12.2016]. 
Wojciech W. Kowalski

Article 111(1) of this Code provides that, in addition to categories of cultural goods such as collections of museums, archives, etc., which are specified in detail, cultural goods also include "other goods of a significant importance for the cultural heritage from the point of view of history, art or archaeology." ${ }^{10}$

Since parallel definitions in nearly all European countries are generally as broad, it can be concluded that the application of the regime of Directive 2014/60/EU with respect to specific cultural goods will be determined in practice by the relevant administrative authorities. As pointed out in the literature, EU Member States have thus obtained an "almost unlimited freedom to define what is and what is not a cultural object which can be classified as a national treasure. Consequently, the spirit and the provisions of the Directive allow for creative and wide protection." ${ }^{11}$ It is not expected, however, that such claims will be made on a mass scale, given that under the far more restrictive Council Directive 93/7/EEC the number was very small, ${ }^{12}$ and the situation has not changed significantly.

The problem is exacerbated by references in these definitions to vague and ambiguous terms, which do not facilitate the classification of objects as historical objects even within the internal systems of states. Polish law provides a typical example of this situation. In accordance with Article 3(1) of the Act on the Protection and Guardianship of Monuments (hereinafter: APGM) ${ }^{13}$ a historical object is considered as "real or movable property, their parts or complexes, which are the work of a human being, or are connected with their activity, and constitute a testimony of a bygone era or a past event, the preservation of which is in the social interest because of the historical, artistic or scientific value thereof."

As I have already broadly discussed in earlier publications,${ }^{14}$ while the terms included in this definition seem to be simple and obvious enough, their practical identification in the case of a specific historical object is often difficult, as it is necessary

\section{Article L $111-1$ code du patrimoine:}

"Sont des trésors nationaux: $1^{\circ}$ Les biens appartenant aux collections des musées de France; $2^{\circ}$ Les archives publiques, au sens de l'article L. 211-4, ainsi que les biens classés comme archives historiques en application du livre II; $3^{\circ}$ Les biens classés au titre des monuments historiques en application du livre $\mathrm{VI} ; 4^{\circ}$ Les autres biens faisant partie du domaine public mobilier, au sens de l'article L. 2112-1 du code général de la propriété des personnes publiques; $5^{\circ}$ Les autres biens présentant un intérêt majeur pour le patrimoine national au point de vue de l'histoire, de l'art ou de l'archéologie."

11 As emphasized by P. Stec, op. cit., p. 112.

12 Ibidem, pp. 109-112.

13 Ustawa z dnia 23 lipca 2003 r. o ochronie zabytków i opiece nad zabytkami [Act on the Protection and Guardianship of Monuments] (consolidated version), Dz. U. 2014, issue 1446, as amended.

14 Compare: W. Kowalski, Prawna problematyka konserwacji zabytków, in: B. Szmygin (ed.), Współczesne problemy teorii konserwacji w Polsce, Wydawnictwo Politechniki Lubelskiej, Warszawa - Lublin 2008, pp. 51 ff.; idem, Prawo ochrony zabytków w świetle aktualnych problemów ochrony dziedzictwa kulturowego Polski, in: W. Szafrański, K. Zalasińska (eds.), Wokół problematyki prawnej zabytków i dzieł sztuki, Wydawnictwo Poznańskie, Poznań 2009, pp. 73 ff.; idem, K. Zalasińska, Prawo ochrony dziedzictwa kulturowego w Polsce - próba oceny i wnioski, in: B. Szmygin (ed.), System ochrony zabytków w Polsce - analiza, diagnoza, propozycje, Wydawnictwo Politechniki Lubelskiej, Lublin - Warszawa 2011, p. 17 ff. 
to interpret two fundamental phrases included in this definition, i.e. "a testimony of a bygone era or a past event" and "historical, artistic or scientific value". The former term - a "bygone era" - undoubtedly refers to remoteness in time, but the Article then states "or a past event", i.e. an event which has already occurred, even recently; thus creating a dual criterion for the periodisation of history which is difficult to apply in practice, as it requires identification of the end of a particular era. It may be assumed that an object qualified as a historical object must actually come from an era that has already gone by, i.e. a historical period that is already over. Indeed, the Polish restoration service considers the period of so-called "socialist realism" as such a closed era, which is manifested in its inclusion on the register of a number of historical objects typical for this era, such as, inter alia, the Zagłębie Palace of Culture in Dąbrowa Górnicza built in 1958 or the Palace of Culture and Science in Warsaw erected in 1955, which were entered in the register in 1979 and 2007 respectively. Recently, however, objects created much later, which are difficult to explicitly prescribe to some closed historical era, have been entered in the register as well. These include, for example, the "Smyk" department store and the stations of the Warsaw cross-city railway line built in the 1960s, Jerzy Nowosielski's paintings of the 1970s in the church in Wesota, ${ }^{15}$ and objects referred to as "modern architecture and historical art".

The aforementioned examples, with one exception, refer to immovable historical properties, but the provisions relating to them also regard movable objects, to which the 2014 Directive also applies. Therefore, generally the above-mentioned entries in the register undoubtedly present difficulties in the application of the definition of "historical object" under APGM, which is based, inter alia, on the concept of historical value determined by the requirement that the object needs to come from a "bygone era".

The practical application of the criterion of "historical, artistic or scientific value" is even more difficult. A detailed analysis of this criterion, performed elsewhere in light of Polish and international law, helped to establish that "historical value" of an object means its documentary value in terms of the role and importance of this object in history, for example, as a testimony of the course of history, various events, peoples' activities, the development of art, technology, etc. The existence of this value in a specific case is determined by the state in which the object is preserved, i.e. its integrity and authenticity. These attributes are critical to the recognition of an object as valuable (also in terms of the other values, namely, scientific and artistic ones). Scientific value includes issues related to technology, design, material, etc., the examination of which may provide important information on old techniques, methods of work, or raw materials used. Regarding artistic value, these

15 W. Kowalski, Prawno-autorskie aspekty ochrony dziedzictwa kulturowego, in: A. Jagielska-Burduk, W. Szafrański (eds.), Kultura w praktyce. Zagadnienia prawne, Vol. 2, Poznańskie Towarzystwo Przyjaciół Nauk, Poznań 2013, p. 182. 


\section{RESEARCH ARTICLES}

Wojciech W. Kowalski

are the individual aesthetic features of the historical object, i.e. the impact of the beauty embodied in it on a wider audience.

The issues related to the above definition cannot be considered in the context of exports without taking into consideration that the provisions relating to export controls provided for in the APGM do not prohibit, under the applicable legislation, the export of movable historical objects of a relatively lower value. Pursuant to Article 51 APGM it is permissible to export from Poland, without a relevant licence, historical objects listed in 15 categories of items that are defined by their age and possible market value. A licence is not required with respect to: exports of archaeological material which is less than 100 years old (Article 51(1)(1) APGM); paintings which are less than 50 years old with a value of less than PLN 40,000 (Article 51(1)(3) APGM); and sculptures which are less than 50 years old with a value of less than PLN 20,000 (Article 51(1)(7) APGM).

It follows that the Polish legislator, unlike in France, has not yet clearly established the basis for applying for the return of numerous exported historical objects, even though this is explicitly allowed under the new 2014 Directive, and if the export is legal applying for its return pursuant to this Directive is inadmissible. As has already been mentioned, this is the current legal status today, more than a year and a half after Directive 2014/60/EU entered into force; obviously it can change. The APGM should be subjected to a thorough analysis and revision, as the enormous losses of cultural heritage during wartime indicate that it could be important for Poland, for example, in cases where an object having a significant symbolic meaning, due to its association with a particular important event or historical occurrence, was exported. At present, an object(s) return may be difficult or even impossible, but the situation would change if the above-cited Article 51 APGM, which allows for exports of historical objects with a lower market value, was repealed. In such an event, in order to apply for the return of such an object, the exporting entity would have to demonstrate that the object is not a historical object within the meaning of Article 3(1) APGM. Because of the general nature of the definition of a historical object, this would not be easy.

At this point it is also worthwhile to pay attention to the implementation of Directive 2014/60/EU in the context of Polish legislation, as the APGM includes a special chapter devoted to the "return of cultural objects unlawfully removed from the territory of a Member State of the European Union". ${ }^{16}$ The provisions of this chapter determine the conditions whereby Poland will return objects unlawfully removed from other states. Despite the entry into force of Directive 2014/60/EU, these provisions still impose restrictions on return based on the 14 categories of historical objects, defined by the object, age and market value, contained in Council Directive 93/7/EEC. In other words, the APGM has not yet been adapted to the new EU legislation that, as explained above, no longer contains such restrictions.

16 Chapter 6 APGM, entitled: "Restitution of historical objects removed unlawfully from the territory of a Member State". 
Another aspect of Poland's participation in the protection of the cultural heritage of a European Union Member State which requires discussion here is the fulfilment of Poland's obligations under the Agreement on cooperation and mutual assistance on detaining and returning cultural goods illegally transferred across borders, concluded in Plovdiv in 1986 (hereinafter: Plovdiv Agreement). ${ }^{17}$ Importantly, this agreement was signed at the time by three countries which are now EU Member States, namely Bulgaria, Hungary and Poland, and according to information received from the treaty archives of the Ministry of Foreign Affairs, this agreement remains in force in Poland. ${ }^{18}$ This fact alone does not pose a problem, since the agreement obliges the signatory states to far-reaching cooperation and collaboration, and thus the agreement could be applied in appropriate cases as a special addendum to the Directive 2014/60/EU. The agreement also provides for other solutions, not stipulated in the Directive, namely that all activities relating to the return of cultural goods illegally transferred across borders shall be performed by the customs authorities of the exporting and importing countries (Article 6 of the Plovdiv Agreement). Pursuant to Article 7 of this Agreement, these bodies "shall afford one another free assistance" in the implementation of the agreement, with the exception of costs of storage, transport, and return which shall be incurred by the exporting country. Goods are returned somehow "automatically" to the authorised bodies of the state, which also investigate "all claims related to the return of cultural property" (Article 6 of the Plovdiv Agreement). Directive 2014/60/EU does not provide for such a procedure of return, as each request has to be considered by the competent court of the "requesting state" (Article 6 of the Directive). A comparison of these provisions indicates that the procedure set out in the agreement is simpler, faster and certainly more cost-effective than the procedure provided for by the Directive. The question remains whether these three countries will apply it in a completely new situation, i.e. after their accession to the European Union and implementation of Directive 2014/60/EU. It seems that this agreement could serve as a complementary act, offering a better option for fast and cost-free action if needed, as its coexistence with EU law is not precluded.

The Council Regulation (EEC) No. 3911/92 of 9 December 1992 on the Export of Cultural Goods is an element of the European system for controlling the export of cultural goods (hereinafter: Regulation No. 3911/92). ${ }^{19}$ Unlike the Directive, this

17 Porozumienie o współpracy i pomocy wzajemnej w sprawie zatrzymywania i zwrotu dóbr kultury nielegalnie przewożonych przez granice państw sporządzone w Płowdiw dnia 22 kwietnia 1986 r. [Agreement on cooperation and mutual assistance concerning detaining and return of cultural goods illegally transferred through borders, Plovdiv, 22 April 1986], Dz. U. 1988, No. 38, item 296.

18 According to the treaty database of the Ministry of Foreign Affairs as of 22 December 2016, the Ministry of Culture and Art, i.e. now the Ministry of Culture and National Heritage, is the Polish competent authority as regards the performance of this agreement.

19 As amended by Council Regulation (EC) No. 116/2009 of 18 December 2008 on the export of cultural goods (codified version), OJ L 39, 10.02.2009, p. 1. 


\section{RESEARCH ARTICLES}

Wojciech W. Kowalski

document does not refer to national regulations, but introduces uniform community rules for controlling exports in the entire area of the $\mathrm{EU}$, and more precisely "outside the customs territory of the Community" (Article 2(1) of the Regulation No. 3911/92). Such controls shall be based on an export licence that authorises its holder to remove the specified cultural goods. However, it is not required to hold this licence at the external borders of the EU for each exported item of cultural property, but only for goods of a greater cultural and/or market value which qualify for one of the 14 categories defined in the Annex to the Regulation which are identical to the categories that were part of the previous Council Directive 93/7/EEC. Thus, as already mentioned licences are required, for example, only for a painting with a value in excess of EUR 150,000; old prints which were at least one hundred years old prior to export and have a value is more than EUR 50,000; and maps which are more than 200 years old and worth more than EUR 15,000, etc. ${ }^{20}$

A comparison of Directive 2014/60/EU and the Regulation No. 3911/92 (as amended by Council Regulation (EC) No. 116/2009) clearly demonstrates that the trade in cultural goods within the EU is strictly controlled, while external trade is subject to significantly less control. In practical terms this is because less valuable objects that the Directive states cannot be moved between EU Member States, or if exported must be returned, can, despite a ban on their export according to the law of a Member State, leave the EU territory and their return will be very difficult, if not impossible. This is because of the lack of universally applicable standards requiring the return of cultural goods exported in violation of the law of the exporting country. The aim of the 1995 UNIDROIT Convention is to establish such standards, but they are not yet universally applicable because at present only 37 states have acceded to the Convention. Poland is not yet a party to the Convention, but work aimed at becoming bound by its provisions is underway. Thus it is appropriate to characterize its main solutions and consider how the ratification of the treaty might affect Poland.

Besides combating the theft of cultural goods, the main purpose of the 1995 UNIDROIT Convention is to prevent their illegal export. To this end, the Convention provides for "claims of an international character aiming at the return of cultural objects removed from the territory of a Contracting State contrary to its law regulating the export of cultural objects because of their cultural significance" (Article 1 of the 1995 UNIDROIT Convention).

The legal basis and mechanism to ensure that such claims are successfully handled are clearly and strictly set out in Article 5(3), which stipulates that "the court or other competent authority of the State addressed shall order the return of an illegally exported cultural object [...]". Inasmuch as this provision is strict, in order to balance the various interests involved in such situations the range of historical

20 Regulation No. 3911/92, Annex, Categories of cultural objects covered by Article 1(A)(3), (A)(9) and (A)(10). 
objects recoverable due to their illegal export has been limited. To be able to order the return of an illegally exported cultural object:

the requesting State [must establish] that the removal of the object from its territory significantly impairs one or more of the following interests: (a) the physical reservation of the object or of its context; (b) the integrity of a complex object; (c) the preservation of information of, for example, a scientific or historical character; (d) the traditional or ritual use of the object by a tribal or indigenous community; or establishes that the object is of significant cultural importance for the requesting State.

As has already been mentioned, each case must prove the relevant sub-provision i.e. the request for the return of an illegally exported cultural object must include all the relevant factual or legal information that will prove an illegal export occurred, and such information should be attached to the request. ${ }^{21}$

Regarding time limitations, two basic periods have been stipulated. First, the time period for lodging a request is three years from the time when the requesting State establishes the location of the cultural object and the identity of its possessor (Articles 3(3) and 5(5) of the 1995 UNIDROIT Convention). ${ }^{22}$ The second time period is an absolute period of fifty years, running uninterrupted from the date of the illegal export (Article 3(3) in fine and Article 5(5) in fine of the 1995 UNIDROIT Convention). It should be noted that the latter period does not apply to claims for the restitution of cultural objects belonging to, and used by, a tribal or indigenous community as part of that community's traditional or ritual use (Article 3.8).

The question of compensation has been addressed as follows:

The possessor of a cultural object who acquired the object after it was illegally exported shall be entitled, at the time of its return, to payment by the Requesting State of fair and reasonable compensation, provided that the possessor neither knew nor ought reasonably to have known at the time of acquisition that the object has been illegally exported.

Article 6(1) of the 1995 UNIDROIT Convention

These "due diligence requirements" while purchasing an illegally exported object encompass the examination of the circumstances of the acquisition, including the absence of an export certificate required under the law of the requesting State (Article 6(2)). The payer is identified directly; pursuant to Article 6(1) of the Convention this is the state requesting the return of the illegally exported cultural object. The compensation is to be paid must be a fair and reasonable amount (Ar-

\footnotetext{
21 "Any request [...] shall contain or be accompanied by such information of a factual or legal nature as may assist the court or other competent authority of the State addressed in determining whether the requirements of paragraphs 1 to 3 have been met" (Article 5(4)).

22 "Any claim for restitution shall be brought within a period of three years from the time when the claimant knew the location of the cultural object and the identity of its possessor, and in any case within a period of fifty years from the date of the export [...]" (Article 5(5)).
} 
Wojciech W. Kowalski

ticle 6(1)) that shall be determined in each case by the court, or other authorised institution, ordering the return of the object covered by the claim.

Concluding the analysis of the procedure for the return of an illegally exported cultural object, it should be noted that an object(s) possessor can agree with the requesting State that, instead of claiming compensation, it will: (a) retain the ownership of the object, or (b) transfer ownership against payment or gratuitously to a person of his/her choice residing in the requesting State who provides the necessary guarantees ${ }^{23}$ This provision arose from the proposal that an illegally exported cultural object may be physically returned to the country from which it was illegally exported, without surrendering ownership of the cultural property. Finally, it can be added that the regulation does not apply in cases where the export in question has ceased to be banned at the time of the request for its return, or if the export took place during the lifetime of the person who created it, or within a period of fifty years following the death of that person. This last condition is without prejudice to the provisions concerning a cultural object made by a member(s) of a tribal or indigenous community for traditional or ritual use by that community; such an object must be returned to that community. ${ }^{24}$

In light of the foregoing, there can be no doubt that the 1995 UNIDROIT Convention can be an effective instrument for protecting the national cultural heritage of states against the loss of movable components through illegal exports. However, in order for it to be effective, the Convention needs to be ratified by the greatest possible number of countries. As mentioned above, at present there are only 37 States Parties to this Convention. Nonetheless, we may wonder why our country, Poland, ten years after the adoption of the Convention and despite the active participation of the Polish delegation, have not yet ratified the Convention.

While indicating that the 1995 UNIDROIT Convention could, following its wide ratification, constitute a universal remedy for the fight against illegal exports of cultural objects, we should not forget about the 1970 UNESCO Convention, which has been in force for almost half a century. ${ }^{25}$ This instrument allows for the return of illegally exported cultural property, including that outside the European Union, but is limited to objects that have been stolen, and subject to certain further conditions.

\footnotetext{
23 "Instead of compensation, and in agreement with the requesting State, the possessor required to return the cultural object to the State, may decide : (a) to retain ownership of the object; or (b) to transfer ownership against payment or gratuitously to a person of its choice residing in the requesting State who provides the necessary guarantees" (Article 6(3) of the 1995 UNIDROIT Convention).

24 "Notwithstanding the provision of sub-paragraph (b) of the preceding paragraph, the provisions of this Chapter shall apply where a cultural object was made by a member or members of a tribal or indigenous community for traditional or ritual use by that community and the object will be returned to that community" (Article 7(1)(2)).

25 See L.V. Prott, Strengths and Weaknesses of the 1970 Convention: An Evaluation 40 years after its adoption, Background paper ( $2^{\text {nd }}$ edition), Second Meeting of States Parties to the 1970 Convention Paris, UNESCO Headquarters, 20-21 June 2012.
} 
Article 7 of the 1970 UNESCO Convention, imposes two basic obligations which State Parties must fulfil under their legal systems. On the one hand, states should prevent the import of cultural property stolen from a museum or a religious or secular public monument or similar institution, provided that these goods are appropriately documented as belonging to the inventories of these institutions (Article $7(b)(i)) .{ }^{26}$ On the other hand, State Parties have to work together to bring about the return of such goods if they have been imported into their territories (Article 7(b)(ii)).

Regarding the first obligation, it should be noted that it establishes a very narrow scope of protection, as it applies only to cultural objects from public collections, and within this category only to those that are inventoried in such an institution (Article 7(b)(I) of the 1970 UNESCO Convention). As highlighted in the literature, in practice this obligation may not include many objects located in churches or belonging to church institutions, ${ }^{27}$ as such objects are often, especially in the countries of Central and Eastern Europe, not inventoried. ${ }^{28}$

The latter obligation led to the development, at the time of the adoption of the 1970 UNESCO Convention, of a new procedure for the restitution of cultural objects stolen from public collections. It provides that at the request of the State Party of origin, made through diplomatic channels, the requested State shall take appropriate steps to recover and return any such goods, provided that the requesting State shall pay just compensation to an innocent purchaser or to a person who has valid title to the property. ${ }^{29}$ Initially, this procedure roused some doubts, ${ }^{30}$ but Patrick J. O'Keefe correctly stated that a refusal to initiate proceedings within the framework specified here would constitute a violation of the obligation of a State Party under Article 7 of this international law instrument. ${ }^{31}$

26 "The States Parties to this Convention undertake: [...] to prohibit the import of cultural property stolen from a museum or a religious or secular public monument or similar institution in another State Party to this Convention [...], provided that such property is documented as appertaining to the inventory of that institution [...]" (Article 7 (b)(i)).

27 P.J. O'Keefe, Commentary on the UNESCO 1970 Convention on Illicit Traffic, Institute of Art and Law, Leicester 2000, p. 61.

28 W. Kowalski, Theft and Illegal Traffic in Works of Art in Poland, "International Criminal Police Review" 1994, Vol. 448-449, pp. $11 \mathrm{ff}$.

29 "The States Parties to this Convention undertake: [...] at the request of the State Party of origin, to take appropriate steps to recover and return any such cultural property imported after the entry into force of this Convention in both States concerned, provided however, that the requesting State shall pay just compensation to an innocent purchaser or to a person who has a valid title to that property. Requests for recovery and return shall be made through diplomatic offices. The requesting Party shall furnish, at its expense, the documentation and other evidence necessary to establish its claim for recovery and return [...]" (Article 7(b)(ii)).

30 Among others see: J.B. Gordon, The UNESCO Convention on the Illicit Movement of Art. Treasures, "Harvard International Law Journal" 1971, Vol. 12, p. 551; S.A. Wiliams, The International and National Protection of Movable Cultural Property. A Comparative Study, Oceana, New York 1978, pp. 84 and 85. For resume of this discussion, see P J. O'Keefe, op. cit., pp. $61 \mathrm{ff}$.

31 P.J. O'Keefe, op. cit., p. 64. 


\section{RESEARCH ARTICLES}

Wojciech W. Kowalski

In light of the foregoing, it can be concluded that the 1970 UNESCO Convention provides an effective tool for the recovery of illegally exported cultural property, including outside the European Union, but its application is limited to objects that have been stolen. Its strong point is undoubtedly the fact that at present there are 131 States Parties who have ratified the Convention. ${ }^{32}$ The effectiveness of the Convention with respect to Poland can be evidenced by the return of a manuscript from the eighth century stolen from Greece, which the National Library in Warsaw purchased in the early 1990s from a Polish citizen working in Polish-Greek tourist services. ${ }^{33}$ It is worth noting that Poland, which has been a Party to the Convention since 1974, returned this manuscript on its own initiative after determining that it originated from the library of one of the monasteries on Mount Athos.

The protection of national cultural heritage from illegal export may also be possible by concluding special bilateral agreements between states particularly concerned about such export. The agreement concluded in 2001 between the United States and Italy, concerning the imposition of import restrictions on categories of archaeological material representing the pre-classical, classical and imperial Roman periods of Italy, ${ }^{34}$ serves as an example of such an initiative. Under the agreement, the US authorities undertook to limit the import of archaeological material from the period of the $9^{\text {th }}$ century $B C$ to the $4^{\text {th }}$ century $A D$, unless specific objects from this period were imported on the basis of relevant documents authorizing their legal export from Italy. A detailed list of such objects must be disseminated by customs' authorities, and a seized object offered to be returned to the Italian authorities.

Another example of such an agreement, albeit a multilateral one, is the previously Plovdiv Agreement concluded in 1986 on cooperation and mutual assistance concerning the detention and return of cultural goods illegally transferred across borders. As was mentioned, it was signed at the time by three countries that are now EU Member States, namely Bulgaria, Hungary and Poland. Given the political changes that have occurred in Central and Eastern Europe in 1990s, the status of the other parties to this agreement is unclear.

In conclusion, it can be said that the existing system of international export controls over works of art are quite complicated, as it consists of a number of various legal instruments covering several fields and protecting different interests. The European Union legislation currently in force offers the real possibility of protection of the integrity of a Member State's cultural heritage, although it remains unclear whether it will bring about the expected results. Considering that states rarely used the much narrower Council Directive 93/7/EEC, it cannot be assumed

32 As of 4 March 2016.

33 W. Kowalski, Nabycie własności dzieła sztuki od nieuprawnionego, Zakamycze, Kraków 2004, p. 198.

34 Agreement between the Government of the United States of America and the Government of the Republic of Italy Concerning the Imposition of Import Restrictions on Categories of Archaeological Material Representing the Pre-Classical, Classical and Imperial Roman Periods of Italy, 19 January 2001, 40 ILM 1031. 
that they will take greater advantage of Directive 2014/60/EU just because the chances of getting back illicitly exported objects are formally greater. Other questions are posed by the broad and sometimes unclear provisions of national legal acts, or the lack of properly updated regulations, as has been discussed in the context of Poland.

The 1995 UNIDROIT and 1970 UNESCO Conventions serve as important parts of the system, but their scope of application is limited due to their own legal restrictions and the currently unsatisfactory number of states parties. Obviously, however, this provides a poor excuse for not ratifying these conventions, as they still provide useful legal means to combat the illicit export of cultural objects. Taking into account the cultural heritage losses Poland has suffered, it should join the 1995 UNIDROIT Convention as soon as possible. Finally, it should be mentioned that, particularly in the case of Poland, concluding special bilateral agreements with certain states protecting the integrity of cultural heritage could be very effective at bringing positive results, especially if the agreement is with neighbouring states.

\section{References}

Agreement between the Government of the United States of America and the Government of the Republic of Italy Concerning the Imposition of Import Restrictions on Categories of Archaeological Material Representing the Pre-Classical, Classical and Imperial Roman Periods of Italy, 19 January 2001, 40 ILM 1031.

Code du patrimoine (consolidated version), https://www.legifrance.gouv.fr/affichCode. do?cidTexte=LEGITEXT000006074236 [accessed: 12.12.2016].

Compagna A.M., Petraroia P. (eds.), Beni culturali e Mercato Europeo. Norme sull'esportazione nei paesi della Comunità, IPZS, Roma 1991.

Council Directive 93/7/EEC of 15 March 1993 on the return of cultural objects unlawfully removed from the territory of a Member State, OJ L 74, 27.03.1993, p. 74.

Council Regulation (EC) No. 116/2009 of 18 December 2008 on the export of cultural goods (codified version), OJ L 39, 10.02.2009, p. 1.

Council Regulation (EEC) No. 3911/92 of 9 December 1992 on the export of cultural goods, OJ L 395, 31.12.1992, p. 1, as amended.

De Ceuster J., Les règles communautaires en matière de restitution de biens culturels ayant quitté illicitement le territoire d'un Etat membre Analyse de la directive 93/7/CEE du 15 mars 1993, "Revue du Marché Unique Européen" 1993, Vol. 2.

Directive 2014/60/EU of the European Parliament and the Council of 15 May 2014 on the return of cultural objects unlawfully removed from the territory of a Member State and amending Regulation (EU) No. 1024/2012 (Recast), OJ L 159, 28.05.2014, p. 1.

Gordon J.B., The UNESCO Convention on the Illicit Movement of Art. Treasures, "Harvard International Law Journal" 1971, Vol. 12.

Kowalski W., Nabycie własności dzieła sztuki od nieuprawnionego, Zakamycze, Kraków 2004.

Kowalski W., Prawna problematyka konserwacji zabytków, in: B. Szmygin (ed.), Współczesne problemy teorii konserwacji w Polsce, Wydawnictwo Politechniki Lubelskiej, Warszawa - Lublin 2008, 
Wojciech W. Kowalski

Kowalski W., Prawno-autorskie aspekty ochrony dziedzictwa kulturowego, in: A. Jagielska-Burduk, W. Szafrański (eds.), Kultura w praktyce. Zagadnienia prawne, Vol. 2, Poznańskie Towarzystwo Przyjaciół Nauk, Poznań 2013.

Kowalski W., Prawo ochrony zabytków w świetle aktualnych problemów ochrony dziedzictwa kulturowego Polski, in: W. Szafrański, K. Zalasińska (eds.), Wokół problematyki prawnej zabytków i dzieł sztuki, Wydawnictwo Poznańskie, Poznań 2009.

Kowalski W., Theft and Illegal Traffic in Works of Art in Poland, "International Criminal Police Review" 1994, Vol. 448-449.

Kowalski W., Zalasińska K., Prawo ochrony dziedzictwa kulturowego w Polsce - próba oceny i wnioski, in: B. Szmygin (ed.), System ochrony zabytków w Polsce - analiza, diagnoza, propozycje, Wydawnictwo Politechniki Lubelskiej, Lublin - Warszawa 2011.

Loi no 2015-195 du 20 février 2015 portant diverses dispositions d'adaptation au droit de l'Union européenne dans les domaines de la propriété littéraire et artistique et du patrimoine culturel [Law No. 2015-195 of 20 February 2015 adapting various provisions of the law of the European Union law in the fields of literary and artistic property and cultural heritage], NOR: MCCB1421649L.

O'Keefe P.J., Commentary on the UNESCO 1970 Convention on Illicit Traffic, Institute of Art and Law, Leicester 2000.

Porozumienie o współpracy i pomocy wzajemnej w sprawie zatrzymywania i zwrotu dóbr kultury nielegalnie przewożonych przez granice państw sporządzone w Płowdiw dnia 22 kwietnia 1986 r. [Agreement on cooperation and mutual assistance concerning detaining and return of cultural goods illegally transferred through borders, Plovdiv, 22 April 1986], Dz. U. 1988, No. 38, item 296.

Prott L.V., Commentary on the UNIDROIT Convention, Institute of Art and Law, Leicester 1997.

Prott L.V., Strengths and Weaknesses of the 1970 Convention: An Evaluation 40 years after its adoption, Background paper ( $2^{\text {nd }}$ edition), Second Meeting of States Parties to the 1970 Convention Paris, UNESCO Headquarters, 20-21 June 2012.

Stec P., Dyrektywa 93/7/EWG z perspektywy dwóch dekad funkcjonowania [Directive 93/7/EEC: a twenty-year retrospective], "Santander Art and Culture Law Review" 2015, Vol. 1(1).

Treaty on the Functioning of the European Union (consolidated version), OJ C 202, 7.06.2016, p. 47.

UNESCO Convention on the Means of Prohibiting and Preventing the Illicit Import, Export and Transfer of Ownership of Cultural Property, 14 November 1970, 823 UNTS 231.

UNIDROIT Convention on Stolen or Illegally Exported Cultural Objects, 24 June 1995, 34 ILM 1322.

UNIDROIT Convention on Stolen or Illegally Exported Cultural Objects: Explanatory Report, "Uniform Law Review" 2001, Vol. 3.

Ustawa z dnia 23 lipca 2003 r. o ochronie zabytków i opiece nad zabytkami [Act on the Protection and Guardianship of Monuments] (consolidated version), Dz. U. 2014, issue 1446, as amended.

Wiliams S.A., The International and National Protection of Movable Cultural Property. A Comparative Study, Oceana, New York 1978. 